\title{
Exploring the Relationship between Social Environment and Customer Experience
}

\author{
Amir Nasermoadeli ${ }^{1}$, Kwek Choon Ling ${ }^{1}$ \& Erfan Severi ${ }^{1}$ \\ ${ }^{1}$ Faculty of Business and Information Science, UCSI University, Kuala Lumpur, Malaysia \\ Correspondence: Kwek Choon Ling, Faculty of Business and Information Science, UCSI University, No.1, Jalan \\ Menara Gading, UCSI Heights, 56000 Kuala Lumpur, Malaysia. Tel: 60-16-688-6248. E-mail: \\ kwekcl@ucsi.edu.my
}

Received: September 13, 2012 Accepted: October 2, $2012 \quad$ Online Published: December 31, 2012

doi:10.5539/ass.v9n1p130

URL: http://dx.doi.org/10.5539/ass.v9n1p130

\begin{abstract}
The emergence of "experience" as another forms of business offerings (Pine and Gilmore, 1999) and the failure of implementing customer relationship management to create the expected levels of value for customers and profitability for organizations (Palmer, 2010; Barnes, 2002) have prompted the practitioners and academic scholars to explore the successor of customer relationship management, which is known as customer experience. Pine and Gilmore (1999) asserted that companies need to create memorable experiences to each customer for the purpose of generating greater economic value in the experience-based economy, instead of simply making goods and delivering services to the customers (Kim, Cha, Knutson and Beck, 2011). For the purpose of creating differentiated and memorable customer experience, this research paper would like to evaluate the direct and indirect relationship between social environment and customer experience (including sensory experience, emotional experience and social experience). A total of 330 respondents participate in this research. The findings revealed thatsocial environment is related to the sensory experience and emotional experience respectively.Furthermore, the research findings also concluded the interactive relationships between the dimensions of the customer experience: (1) the sensory experience is positively related to the emotional experience; (2) the emotional experience is positively related to the social experience; and (3) the sensory experience is positively related to the social experience.
\end{abstract}

Keywords: social environment, sensory experience, emotional experience, social experience

\section{Introduction}

The failure of implementing customer relationship management to create the expected levels of value for customers and profitability for organizations (Palmer, 2010; Barnes, 2002) has prompted the practitioners and academic scholars to explore the successor of customer relationship management, which is known as customer experience. Pine and Gilmore (1999) asserted that companies need to create memorable experiences to each customer for the purpose of generating greater economic value in the experienced-based economy, instead of simply making goods and delivering services (Kim, Cha, Knutson and Back, 2011). Verhoef, Neslin and Vroomen (2007) had argued that the social environment can influence the customer experience in the retail environment. The current literature reviews only evaluate the direct impact of social environment on sensory experience, emotional experience and social experience respectively (Graven and Browne, 2008; Parkinson, 1996; Moretz and Robison, 2007). There is a lacking of study to evaluate the indirect (mediating) relationships among social environment, sensory experience, emotional experience and social experience. Thus, this research paper will empirically evaluate to what extent social environment can directly and indirectly affect the dimensions of customer experience.

\section{Literature Review}

\subsection{Customer Experience}

The concept of customer experience was intimately conceived in the mid-1980s when Holbrook and Hirschman (1982) introduce a new experiential approach into the consumer behaviour domain. Current extant literature has made the point that the customer experience may provide a new mean of competition, especially in the era of experience economy (Pine and Gilmore,1999; Shaw and Ivens, 2002; Meyer and Schwager, 2007). However, the 
term of "customer experience" had been defined in various ways in the extant literature. There are no consensus in defining customer experience due to the nature of customer experience is a multidimensional construct that has been a part of studies spanning across various fields (Walls, Okumus, Wang and Kwun, 2012). The concept of customer experience can be explained through various academic disciplines. For the sociological and psychological perspective, peak experience is defined as "subjectively recognized to be one of the high points of life, one of the most exciting, rich and fulfilling experiences which the person has ever had" (Thorne, cited in Walls et al., 2011, p.11). From the anthropological and ethnological perspectives, the extant literatures argue that individual experience is affected by the surrounding culture (Caru and Cova, cited in Walls et al., 2011) and society (Abrahams, cited in Walls et al., 2011). From the perspective of economic and marketing perspectives, Schmitt (1999) argued that customer experience is created via some stimulations and self involvement in an event. Lewis and Chambers (2000, p.46) defined consumer experience as "the total outcome to the customer from the combination of environment, goods and services purchased". Customer experience can be also defined based on cognitive as well as affective and process based approaches. Based on the cognitive definitions of experience, the Oxford English Dictionary described experience as "active participation in events or activities, leading to the accumulation of knowledge or skill" (OUP, 2006). Based on the affective and process based definition, the American Heritage Dictionary of the English Language (2006) defined experience as "the feeling of emotions and sensations as opposed to thinking" and "...involvement in what is happening rather than abstract reflection on an event". In addition, customer experience can be defined based on the utilitarian and hedonic approaches. Based on the utilitarian view, Abbot (cited in Palmer, 2010, p.197) argued that "experience as being the transformation of products into value as perceived by the consumer". From the hedonic approach, Schmitt (1999, p.26) asserted that experience "...provide sensory, emotional, cognitive, behavioural and relational values that replace functional values" as well as Gupta and Vajic $(2000$, p.34) stated that "....an experience occurs when a customer has any sensation or knowledge acquisition resulting from some level of interaction with different elements of a context created by the service provider". In conclusion, there is not conclusive definition of customer experience in the extant literature. It made harder to define the dimension of customer experience based on a particular industry context. Thus, the dimensions of customer experience proposed by Yang and He (2011) and Schmitt (1999) will be adopted in this research paper. The proposed dimensions of customer experience consist of sensory experience, emotional experience and social experience. The current extant literature also argues that the social environment does influence the customer experience (Baker et al., 2002; Grewal et al., 2003; Pan and Zinkhan, 2006; Sirohi, McLaughlin and Wittink, 1998; Verhoef, Neslin and Vroomen, 2007). Schmitt (1999) proposedthree dimensions of customer experience, including sensory experience, emotional experience, and social experience. The following paragraph will elaborate social environment, sensory experience, emotional experience and social experience in details.

\subsection{Social Environment}

Pitcher and Magurran (1986); Witte and Ryan (2002); Hamilton and Dill (2003) asserted that social environment consistently creates impact toward individual performance due to the interaction with other people. Besides, social environment can also create indirectly or passively toward actual physical changes (Geva and Bloch, 2005). It has long been argued that the public perceptions of environmental issues depend primarily on the mass media (Downs, 1972), but the effect of the media on the popular attention will be depended on how the content is reviewed by the readers. Therefore, Schoenfeld, Meier and Griffin (1979) recognized that the media plays an ideal part in the social development of environmental issues. In addition, government policy messages (Hepbum and Hepburn, 1985; Nohrstedt, 1991); textual content of the media (Denzin, 1989); and the development of the communities (Powazek, 2001)within the context of social environment do impact the precise relationships between associates and the level of individual environmental concerns respectively. Based on a retail study carried out by Verhoef, Neslin and Vroomen (2007), they concluded that the social environment on the retailing environment does influence the customer experience. The following paragraph will elaborate the dimensions of customer experience in detail.

\subsection{Sensory Experience}

Sensory experience has been defined as the perception view of sensory and aesthetic about product, surroundings, and atmosphere by Nagasawa (2008) and Schmitt (1999). Hulten, Broweus and Dijk (2008) argued that for establishing of sensory experience, both primary senses and experience havebeen contributed together. Vargo and Lusch (2004) argued that consumers' sensory experience has generated both rational and emotional mindsets in the brain. The merges of rational and emotional mindsets within a personal brain have assisted individual to generate the sensory experience within his or her own brain. Gobe (2001) argued that sensory experience facilitates individual to promote identification creation, self-fulfillment and self-image. 
According to Lindstorm (2005), companies should offer sensory experience to their customers by creating the five primaries senses (including of smell, sound, sight, taste and touch) among the customers. Schmitt (1999) believed that companies should use sense marketing technique for the purpose of getting stronger customer sensory by motivating their customers and adding more values to their products.

\subsection{Emotional Experience}

Emotional experience hadbeen defined by Schmitt (1999) as a mood and inner emotions which generating from the shopping trip.Yang and $\mathrm{He}$ (2011) argued that moods and feeling are part of emotional experience which are able to generate effective experience. Based on their research, the effective experience is made of little positive mood and strong emotion joys which by adding the emotional experience to a brand, the company will be able to touch the deep emotion of customers. LeDoux (1996) described emotional experience as how emotions are being created and this creation has explained by feedback, central, arousal, and cognitive theories. If company is able to create a strong emotional experience with its customers, it can be very effective to encourage future purchasing made by customers (Fournier, 1998). According to Arnould and Cost (1993), they had argued that high emotional experience involvement of customer to a service or company can increase customer's purchase intention in the future. Oliver (1997) discussed that emotion is able to affect customer experience and long-term personality intention. In the other point of view, Barsky and Nash (2002) argued that generated emotions from pre-actual and post-consumption periods will create effect on customer experience. Hoyer and McInnis (2001) asserted that emotion can stimulate the formation of consumer's attitude. Price, Arnould and Tierney (1995) argued that emotion plays an important role in shaping customer's product consumption.

\subsection{Social Experience}

Social experience hadbeen defined by Schmitt (1999) as a good or bad relationship between others and society. Based on Schmitt (2003), the generated social experience is able to create effect on personal socializing procedure and subsequently influence his or her thoughts, feelings, and activities. Macionis and Plummer (1997) and Olsen (1993) argued that mass media and peer groups can create a big effect on individuals through the socialization route. In conclusion, social experience does allow individual to identify his or her social community and shape his or her behaviour (Griffiths, 2003).

\subsection{Relationship between Social Environment and Customer Experience}

According to the study carried out by Verhoef, Neslin and Vroomen (2007), determinants such as social environment, service interface, retail atmosphere, assortment, price, customer experiences in alternative channels and retail brand do directly create impact toward the customer experience. The concept of customer experience that illustrated in the Verhoef et al (2007) study encompasses cognitive, effective, social and physical experiences. Built on the Yang and He (2011) and Schmitt (1999) dimensions of customer experience (consisting of sensory experience, emotional experience, and social experience), Graven and Browne (2008) theoretically discovered the direct effect of social environment on sensory experience, especially in the stages of child development. Based on psychosocial approach, Parkinson (1996) theoretically argued that there is a direct effect of social environment on emotional experience. In addition, Moretz, Martins and Robinson (2007) asserted that there is a positive effect of social environment on social experience based on zebrafish (Danio rerio) behavioural study. The above theoretical studies (Graven and Browne, 2008; Parkinson, 1996; Moretz, Martins and Robinson, 2007) yet to be empirically tested to ensure the reality of the relationship. Therefore, the aim of this research would like to empirical testing the hypotheses relationship based on the above studies. 


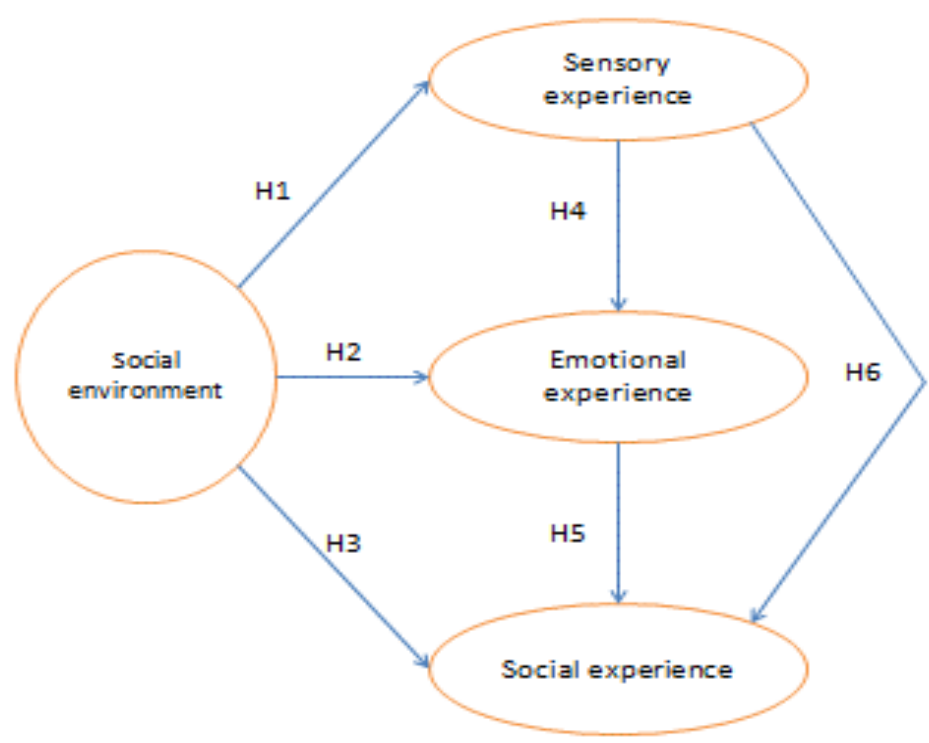

Figure 1. Proposed conceptual framework

In conclusion, this research paper seeks to empirically identify and determine the direct and mediating relationships between the social environment and the dimensions of customer experience through respective tested hypotheses. Figure 1 illustrates the proposed conceptual framework for this research paper.

\subsection{Hypotheses}

From the discussion above, this has led to the development of the proposed conceptual framework as illustrated in Figure 1 and the following hypotheses. The nine hypotheses are as follows:

H1: Social environment is positively related to the sensory experience.

$\mathrm{H} 2$ : Social environment is positively related to the emotional experience.

H3: Social environment is positively related to the social experience.

H4: Sensory experience is positively related to the emotional experience.

H5: Emotional experience is positively related to the social experience.

H6: Sensory experience is positively related to the social experience.

H7: There is a positive significant relationship between the social environment and the emotional experience, mediated by sensory experience.

H8: There is a positive significant relationship between the social environment and the socialexperience, mediated by emotional experience.

H9: There is a positive significant relationship between the social environment and the socialexperience, mediated by sensory experience

\section{Research Methodology}

\subsection{Research Design}

Descriptive research design was adopted as the study has specific hypotheses and detailed body of literature (Malhotra, 2004).

\subsection{Questionnaire Design}

The first part of the questionnaire elaboratedquestions in related to the tested constructs (consisting of social environment, sensory experience, emotional experience and social experience). The second part of the questionnaire identified the personal information of the respondents. The items for the independent variable "social environment" were adopted from T.StaEhla (2001). The items of the questionnaire for the sensory experience, emotional experience, and social experience were adapted from Yang and He (2011). A 5-point Likert scale anchored by "strongly disagree" (1) to "strongly agree" (5) was used as the attitude measurement for all the tested constructs (T.StaEhla et al., 2001; Yang and He, 2011). 


\subsection{Sampling}

The target population in this research is the current full time business students who are studying in one of the private universities in Malaysia. Cross sectional study was conducted in this research. The targeted sample size was 330 and judgemental sampling technique was used to select potential respondents in this survey.

\subsection{Administration of Survey}

Drop-off survey technique was used in this research. The respondents were given copies of self-administered survey questionnaire for the purpose of ensuring the confidentiality and non-obligation aspects of participating in the survey. The voluntary nature of the participation was explained verbally as well as being indicated in the survey questionnaire. A total of 330 sets of questionnaires were distributed and 320 questionnaires were collected. Out of that, 20 sets of questionnaires were considered unusable because they were incomplete whereby over 25 percent of the questions in measuring the tested constructs were not answered (Sekaran, 2003). It was assumed that the respondents were either unwilling to cooperate or not serious with the survey. Therefore, a total of 300 usable questionnaires (92 percent) were used for data analysis by using SPSS software version 20 .

\section{Research Results}

\subsection{Demographic Profile}

Based on the survey, male respondents represented 55 percent of the total respondents while female respondents represented 45 percent. In the case of age distribution, the majority of the respondents were between the ages of 21 to 25 (40.3 percent). In terms of ethnic compositions, the students were mainly Chinese (56\%), followed by Indian (20\%), Malay (14\%) and others (10\%). Based on the categories of current highest academic qualification level, the distribution of the respondents was spread across different levels of tertiary education. The categories of the current highest academic level are mostly in bachelor degree (63\%), master degree $(25 \%)$ and doctoral degree (12\%).

\subsection{Reliability Test}

The reliability of a measure indicates the stability and consistency with which the instrument measures the concept and helps to assess the 'goodness' of a measure (Cavanaet al., 2001).All the constructs were tested for the consistency reliability of the items within the constructs by using the Cronbach alpha reliability analysis. In Table 1, the results indicated that the Cronbach alpha for all the four constructs were well above 0.70 as recommended by Cavana et al. (2001). Cronbach alpha for the constructs ranged from the lowest of 0.765 (Social Environment) to highest 0.948 (Emotional Experience).

Table 1. Reliability test of variables

\begin{tabular}{lc}
\hline \multicolumn{1}{c}{ Variables } & Composite Reliability \\
\hline Social Environment & 0.765 \\
Sensory Experience & 0.818 \\
Emotional Experience & 0.948 \\
Social Experience & 0.876 \\
\hline
\end{tabular}

In conclusion, the results showed that the scores of the Cronbach alpha for all the constructs used in this research exceeded the preferable scores of 0.70 and this indicated that the measurement scales of the constructs were stable and consistent.

\subsection{Validity Test}

Constructs validity was adopted as validity measurement and factor analysis was used to measure the construct validity (Cavana, et al., 2001). The details of the factor analysis were presented in Table 2. Based on the output shown, factor analysis was appropriate because the value of Kaiser-Meyer-Olkin (KMO) was 0.935 (between 0.5 and 1.0) and the statistical test for Bartlett test of sphericity was significant $(\mathrm{p}=0.000$; d.f. $=325)$ for all the correlations within a correlation matrix (at least for some of the constructs). Based on the principal components analysis and VARIMAX procedure in orthogonal rotation, the results also showed that the Eigenvalues for all the constructs were greater than 1.0, ranging from the lowest 1.043 (Social Environment) to the highest of 11.172 (Emotional Experience). In terms of convergent validity, the factor loadings for all items within a construct were more than 0.50 . Discriminant validity indicated that all items were allocated according to the different constructs. Therefore, the items were not overlapping and they supported the respective constructs. 
Table 2. Factors identified by principal components factor analysis

\begin{tabular}{|c|c|c|c|c|c|}
\hline $\begin{array}{l}\text { Factor's } \\
\text { Name }\end{array}$ & Variable & $\begin{array}{l}\text { Factor } \\
\text { Loading }\end{array}$ & $\begin{array}{l}\text { Eigen- } \\
\text { value }\end{array}$ & $\begin{array}{l}\text { Percentage of } \\
\text { Variance } \\
\text { Explained }\end{array}$ & $\begin{array}{l}\text { Cronbach's } \\
\text { Reliability } \\
\text { Coefficients }\end{array}$ \\
\hline \multirow{6}{*}{$\begin{array}{l}\text { Emotional } \\
\text { Experience }\end{array}$} & Happy & 0.800 & 11.172 & 17.721 & 0.948 \\
\hline & Pleased & 0.787 & & & \\
\hline & Relax & 0.754 & & & \\
\hline & Contended & 0.743 & & & \\
\hline & Satisfied & 0.725 & & & \\
\hline & Hopeful & 0.712 & & & \\
\hline \multirow{4}{*}{$\begin{array}{l}\text { Social } \\
\text { Experience }\end{array}$} & Finding a sense of belonging & 0.738 & 1.608 & 10.373 & 0.876 \\
\hline & Positioning social status & 0.701 & & & \\
\hline & Promoting social status & 0.679 & & & \\
\hline & Getting recognized & 0.633 & & & \\
\hline \multirow{4}{*}{$\begin{array}{l}\text { Sensory } \\
\text { Experience }\end{array}$} & Arousing sensation & 0.851 & 1.241 & 10.240 & 0.818 \\
\hline & Bringing interest & 0.789 & & & \\
\hline & Attractiveness & 0.644 & & & \\
\hline & Being worthwhile & 0.633 & & & \\
\hline \multirow{3}{*}{$\begin{array}{l}\text { Social } \\
\text { Environment }\end{array}$} & Surrounding social community & 0.852 & 1.043 & 8.147 & 0.765 \\
\hline & Friends and acquaintances & 0.811 & & & \\
\hline & Media instrument & 0.765 & & & \\
\hline
\end{tabular}

Note:

KMO Measure of Sampling Adequacy $=0.935 ; \mathrm{p}=0.000(\mathrm{p}<0.05) ; \mathrm{df}=325$

Cumulative Percentage Rotation Sums of Squared Loadings $=71.988$

\subsection{Inferential Analysis}

Regression analysis was conducted in the inferential analysis to testify the hypothesized relationships for the respective hypotheses.

\subsubsection{Simple Regression Analysis}

The simple regression "is a procedure for deriving a mathematical relationship in the form of an equation, between a single metric dependent or criterion variable and a single metric independent or predictor variable" (Hair et al., 2006; Malhotra et al., 2006, p.692). Simple regression analysis was carried out to test the first hypothesis (H1).

The result of the simple regression analysis was presented in Table 3. The p value of the Social Environment $(p=0.000)$ is less than the alpha value of 0.05 . The value of the unstandardized beta coefficient is 0.601 . The change of Sensory Experience is explained 12.8 percent by Social Environment. The research concludes that Social Environment is positively related to theSensory Experience. Hypothesis I (H1) is supported.

Table 3. Results of simple linear regression analysis for this research (H1)

\begin{tabular}{cccc}
\hline Variables & Unstandardized Beta Coefficients & t-value & Significant \\
\hline Social Environment & 0.601 & 6.628 & 0.000 \\
\hline
\end{tabular}

Notes:

Dependent variable: Sensory experience; Independent variables: Emotional experience

$\mathrm{R}=35.8$ per cent; $\mathrm{R}$ Square $=12.8$ per cent; Adjusted $\mathrm{R}$ Square $=12.6$ per cent; $\mathrm{F}=43.934 ; \mathrm{P}=0.0001(\mathrm{p}<0.05)$ 


\subsubsection{Multiple Regression Analysis}

\subsubsection{Multiple Regression Analysis ( $\mathrm{H} 2$ and $\mathrm{H} 4)$}

Multiple regression analysis is the appropriate technique to analyze the linear relationship between a dependent variable and multiple independent variables by estimating coefficients for the equation for a straight line (Hair et al. 2006). Multiple regression analysis will be carried out to test two hypotheses (H2 and $\mathrm{H} 4)$ in this research.

The result of the multiple regression analysis for hypothesis 2 was presented in Table 4 . The $p$ value of the Social Environment $(\mathrm{p}=0.018)$ is less than alpha value of 0.05 . However, the value of the unstandardized beta coefficient is -0.569 . Therefore, the research concludes that Social Environment is negatively related to the Emotional Experience. Thus, hypothesis 2(H2) is partially supported.

The result of the multiple regression analysis for hypothesis 4 was presented in Table 4 . The $p$ value of the Sensory Experience $(p=0.000)$ is less than the alpha value of 0.05 . The value of the unstandardized beta coefficient is 1.490. Therefore, the research concludes that Sensory Experience is positively related to the Emotional Experience. Thus, hypothesis 4(H4) is supported.

Table 4. Results of multiple regression analysis for this research (H2 and $\mathrm{H} 4)$

\begin{tabular}{lccc}
\hline \multicolumn{1}{c}{ Variables } & Unstandardized Beta Coefficients & t-value & Significant \\
\hline Sensory Experience (H4) & 1.490 & 10.458 & 0.000 \\
Social Experience (H2) & -0.569 & -2.383 & 0.018 \\
\hline
\end{tabular}

Notes:

Dependent variable: emotional experience

$\mathrm{R}=52.2$ per cent; $\mathrm{R}$ Square $=27.3$ per cent; Adjusted $\mathrm{R}$ Square $=26.8$ per cent; $\mathrm{F}=55.757 ; \mathrm{P}=0.0001(\mathrm{p}<0.05)$

In conclusion, the values of unstandardized beta coefficient among the independent variables tested in the hypotheses ranged from the weakest relationship of -0.569 (social environment and emotional experience) to the strongest relationship of 1.490 (between sensory experience and emotional experience). It may conclude that the sensory experience is the most powerful antecedent in affecting the emotional experience. The change of emotional experience is explained $27.3 \%$ by sensory experience and social environment.

\subsubsection{Multiple Regression Analysis (H3, H5 and H6)}

The result of the multiple regression analysis for the hypothesis 3 was presented in Table 5 . The p value of the social environment $(\mathrm{p}=0.215)$ is more than the alpha value of 0.05 . The value of unstandardized beta coefficient is -0.075 . Therefore, the research concludes that there is no relationship between social environment and social experience. Therefore, hypothesis 3 (H3) is failed to be accepted.

The result of the multiple regression analysis for the hypothesis 5 was presented in Table 5 . The $p$ value of the emotional experience $(\mathrm{p}=0.000)$ is less than the alpha value of 0.05 . The value of unstandardized beta coefficient is 0.220 . Therefore, the research concludes that emotional experience is positively related to the social experience. Hypothesis 5 (H5) is supported.

The result of the multiple regression analysis for the hypothesis 6 was presented in Table 5 . The p value of the sensory experience $(\mathrm{p}=0.001)$ is less than the alpha value of 0.05 . The value of unstandardized beta coefficient is 0.135 . Therefore, the research concludes that sensory experience is positively related to the social experience. Hypothesis 6 (H6) is supported.

Table 5. Results of multiple regression analysis for this research (H3, H5 and H6)

\begin{tabular}{lccc}
\hline \multicolumn{1}{c}{ Variables } & Unstandardized Beta Coefficients & t-value & Significant \\
\hline Sensory Experience (H6) & 0.135 & 3.241 & 0.001 \\
Emotional Experience (H5) & 0.220 & 15.185 & 0.000 \\
Social Environment (H3) & -0.075 & -1.243 & 0.215 \\
\hline
\end{tabular}

Notes:

Dependent variable: social experience

$\mathrm{R}=75.9$ per cent; $\mathrm{R}$ Square $=57.6$ per cent; Adjusted $\mathrm{R}$ Square $=57.1$ per cent; $\mathrm{F}=133.880 ; \mathrm{P}=0.0001$ $(\mathrm{p}<0.05)$ 
In conclusion, the values of unstandardized beta coefficient among the significant independent variables tested in the hypotheses ranged from the weakest relationship of 0.135 (between sensory experience and social experience) to the strongest relationship of 0.220 (between emotional experience and social experience). It may conclude that the emotional experience is the most powerful antecedent in affecting the social experience. In conclusion, the change of social experience is explained $57.6 \%$ percent by a combination of two independent variables, including sensory experience and emotional experience.

\subsubsection{Mediated Regression Analysis (H7, H8 and H9)}

Mediational analysis is used to examine how two variables precede or cause a third variable (refer to dependent variable). According to Howitt and Cramer (2011a, p.330), "the mediating variable may either partly explain the relation between the other predictor variable and the criterion variable or totally explain it. If it partly explains the relation, the other predictor will also partly explain the relation in the absence of additional mediating variables. If it totally explains the relation, the other predictor will only explain the relation through the mediating variable. In other words, the first variable will explain the relation indirectly rather than directly".

To test H7, H8 and H9, the three-step process recommended by Baron and Kenny (1986) was adopted in this study. According to this approach, three separate equations should be estimated: (1) The mediating variable is regressed on the independent variable; (2) The dependent variable is regressed on the independent variable; and (3) The dependent variable is simultaneously regressed on the dependent variable and the mediating variable. As Baron and Kenny (1986, p.1177) say:

"To establish mediation, the following conditions must hold: First, the independent variable must affect the mediator in the first equation; second, the independent variable must be shown to affect the dependent variable in the second equation; and third, the mediator must affect the dependent variable in the thirdequation. If these conditions all hold in the predicted direction, then the effect of independent variable must be less in the third equation than in the second equation. Perfect mediation holds if the independent variable has no effect when the mediator is controlled".

Based on the above quotation, partial mediation is indicated when the independent variable's effect is reduced in magnitude, but is still significant when the mediator is controlled. Based on the recommendation of Baron and Kenny (1986), the results of the three-step process are presented in Table 6(a), 6(b) and 6 (c).

According to the finding from Table 6(a), social environment (independent variable) significantly affected the sensory experience (mediator) in the first equation; social environment (independent variable) did not significantly affect the emotional experience (dependent variable) in the second equation; both social environment (independentvariable) and sensory experience (mediator) significantly affectedemotional experience. Hypothesis 7 (H7) is not supported because not all the three conditions proposed by Baron and Kenny (1986) are supported.

Table 6(a). Result of mediated multiple regression (mediator analysis) (H7)

\begin{tabular}{lccc}
\hline Independent Variable & Sensory Experience (Mediator) & \multicolumn{2}{c}{ Emotional Experience (Dependent Variable) } \\
\cline { 2 - 4 } & Model 1 & Model 2 & Model 3 \\
\hline Social Environment & $0.601^{*}$ & 0.327 & $-0.569^{*}$ \\
& $(\mathrm{p}=0.000)$ & $(\mathrm{p}=0.211)$ & $(\mathrm{p}=0.018)$ \\
& $\left(1^{\text {st }}\right.$ equation $)$ & $\left(2^{\text {nd }}\right.$ equation $)$ & $\left(3^{\text {rd }}\right.$ equation $)$ \\
Sensory Experience & & & $1.490^{*}$ \\
& & & $(\mathrm{p}=0.000)$ \\
& & & $\left(3^{\text {rd }}\right.$ equation $)$ \\
\hline
\end{tabular}

$* \mathrm{p}<0.05$

In conclusion, sensory experience does not act as a mediator in mediating the relationship between social environment and emotional experience.

According to the finding from Table 6(b), social environment (independent variable) did not significantly affect the emotional experience (mediator) in the first equation; social environment (independent variable) did not significantly affect the social experience (dependent variable) in the second equation. For the third equation, social environment (independent variable) did not significantly affect social experience (dependent variable) and only emotional experience (mediator) significantly affected social experience (dependent variable). Hypothesis 8 
(H8) is not supported because all the three conditions proposed by Baron and Kenny (1986) are not matched. In conclusion, emotional experience does not act as a mediator in mediating the relationship between social environment and social experience.

Table 6(b). Result of mediated multiple regression (mediator analysis) (H8)

\begin{tabular}{lccc}
\hline Independent & Emotional Experience (Mediator) & \multicolumn{2}{c}{ Social Experience (Dependent Variable) } \\
\cline { 2 - 4 } & Model 1 & Model 2 & Model 3 \\
\hline Social & 0.327 & 0.078 & -0.002 \\
Environment & $(\mathrm{p}=0.211)$ & $(\mathrm{p}=0.360)$ & $(\mathrm{p}=0.975)$ \\
& $\left(1^{\text {st }}\right.$ equation $)$ & $\left(2^{\text {nd }}\right.$ equation $)$ & $\left(3^{\text {rd }}\right.$ equation $)$ \\
Emotional & & & $0.244^{*}$ \\
Experience & & & $(\mathrm{p}=0.000)$ \\
& & & $\left(3^{\text {rd }}\right.$ equation $)$ \\
\hline
\end{tabular}

$* \mathrm{p}<0.05$

According to the finding from Table 6(c), social environment (independent variable) did not significantly affect the sensory experience (mediator) in the first equation; social environment (independent variable) significantly affected the social experience (dependent variable) in the second equation; both social environment (independent variable) and sensory experience (mediator) did not significantly affect social experience. Hypothesis 9 (H9) is not supported because all the three conditions proposed by Baron and Kenny (1986) are not matched. In conclusion, sensory experience does not act as a mediator in mediating the relationship between social environment and social experience.

Table 6(c). Result of mediated multiple regression (mediator analysis) (H9)

\begin{tabular}{lccc}
\hline Independent & Sensory Experience (Mediator) & \multicolumn{2}{c}{ Social Experience (Dependent Variable) } \\
\cline { 2 - 4 } & Model 1 & Model 2 & Model 3 \\
\hline Social & 0.078 & $0.601^{*}$ & $-0.200^{*}$ \\
Environment & $(\mathrm{p}=0.360)$ & $(\mathrm{p}=0.000)$ & $(\mathrm{p}=0.012)$ \\
& $\left(1^{\text {st }}\right.$ equation $)$ & $\left(2^{\text {nd }}\right.$ equation $)$ & $\left(3^{\text {rd }}\right.$ equation $)$ \\
Sensory & & & $0.462^{*}$ \\
Experience & & & $(\mathrm{p}=0.000)$ \\
& & & $\left(3^{\text {rd }}\right.$ equation $)$ \\
\hline
\end{tabular}

$* \mathrm{p}<0.05$

\section{Conclusion}

\subsection{Conclusion of Hypotheses}

The findings from this research confirm that social environment is related to the sensory experience and emotional experience respectively. Furthermore, the research findings also conclude the interaction relationships between the dimensions of the customer experience: (1) the sensory experience is positively related to the emotional experience; (2) the emotional experience is positively related to the social experience; and (3) the sensory experience is positively related to the social experience.

\subsection{Implications of Research Findings}

\subsubsection{Theoretical Implications}

Based on the extant literature, there is a direct impact of social environment on sensory experience, emotional experience and social experience respectively (Graven and Browne, 2008; Parkinson, 1996; Moretz, Martins and Robinson, 2007). However, the result from this research study only indicates that the social environment does impact on sensory experience and emotional experience respectively. There is not significant relationship between social environment and social experience.

In addition, there is no conclusive empirical result in the extant literature to indicate the interactive relationships between sensory experience, emotional experience and social experience. This research has closed this gap and 
confirms that there are interactive relationships among sensory experience, emotional experience and social experience.

Besides, there is a lack of prior study in the current literature review to investigate the role of mediator in mediating the relationships between the social environment and the dimensions of customer experience (ie., sensory experience, emotional experience and social experience). This research has closed this gap and confirms empirically that there is not mediating relationship between the social environment and the dimensions of customer experience.

\subsubsection{Managerial Implications}

The research findings do provide some insights and feedbacks for the industry players to use social environment as a key factor in influencing customer sensory experience and emotional experience. In addition, the research findings do provide insights to the industry players how to prioritize the customer experience (such as sensory experience, emotional experience and social experience) in the strategy planning because there are interactive relationships among sensory experience, emotional experience and social experience.

\subsection{Limitations of This Research}

Although the research findings present some new insights for the extant literature, these findings should be viewed in light of some limitations.

The study in this research is based on cross-sectional data that is only able to reveal the net effect of predictor variable towards a particular criterion variable at a specific point in time (Cavana et al., 2001). Due to the inherent limitation of cross-sectional study, the research findings are not able to "explain why the observed patterns are there" (Easterby-Smith, Thorpe and Lowe, 2003, p.45). In other words, this research is not able to describe the causality of customer experience based on the observed changes in pattern throughout a period of time.

Besides, the adoption of judgemental sampling method in this study has restricted the generalizable of the research findings.

\subsection{Recommendations for Further Research}

Due to the limitations of this research, a few recommendations are suggested for further research for the purpose of overcoming the above limitations.

Cross-sectional study may not be able to portray the observed changes in patterns. In due respect, longitudinal studies, which repeatedly measure the same sample units of a population over a period of time is proposed to be adopted in the future study (Burns \& Bush, 2003).

Due to the restriction of generalization, it is recommended to adopt probability sampling technique in the future study for the purpose of enhancing the validity and generalization of the research findings.

\section{References}

Arnould, E. A. P., \& Cost, L. (1993). River magic: Extraordinary experiences and the extended service encounter. Journal of Consumer Research, 20(1), 24-45. http://dx.doi.org/10.1086/209331

Baker, J. A., Parasuraman, D. G., \& Voss, G. B. (2002). The influence of multiple store environment cues on perceived merchandise value and patronage intentions. Journal of Marketing, 66(2), 120-141. http://dx.doi.org/10.1509/jmkg.66.2.120.18470

Barnes, J. (2002). Secrets of customer relationship management: It's all about youmake them feel. New York: McGraw-Hill.

Baron, R. M., \& Kenny, D. A. (1986). The moderator-mediator variable distinction in social psychological research: conceptual, strategic, and statistical considerations. Journal of Personality \& Social Psychology, 51, 1173-1182. http://dx.doi.org/10.1037/0022-3514.51.6.1173

Barsky, J., \&. Nash, L. (2002). Evoking emotion: affective keys to hotel loyalty. Cornell Hotel and Restaurant Administration Quarterly, 43(1), 39-46. http://dx.doi.org/10.1016/S0010-8804(02)80007-6

Burns, A., \& Bush, R. (2003). Marketing research: Online research application. New Jersey: Prentice Hall.

Cavana, R. Y. M., Delahaye, B. L., \& Sekaran, U. (2001). Applied business changing information environment (2nd ed.). New York: McGraw-Hill.

Denzin, N. K. (1989). The research act: A theoretical introduction to sociological methods (3rd ed.). New Jersey: Prentice Hall 
Downs, A. (1972). Up and down with ecology. Public Interest, 28, 38-50.

Easterby-Smith, M., Thorpe, R., \& Lowe, A. (2003). Management research: An introduction (2nd ed.). California: SAGE Publications.

Fournier, S. (1998). Consumers and their brands: Developing relationship theory in consumer research. Journal of Consumer Research, 24(4), 343-373. http://dx.doi.org/10.1086/209515

Geve, S. H. K., \& Bloch, G. (2005). Reproductive division of labor, dominance, and ecdysteroid levels in hemolymph and ovary of the bumble bee Bombus terrestris. Journal of Insect Physiology, 51, 811-823. http://dx.doi.org/10.1016/j.jinsphys.2005.03.009

Gobe, M. (2001). Emotional branding: The new paradigm for connecting brands to people. New York: Allworth.

Graven, S. N., \& Browne, J. V. (2008). Sensory developmental in fetus, neonate and infant: Introduction and overview. Newborn Infant Nursing Review, 8(4), 169-172. http://dx.doi.org/10.1053/j.nainr.2008.10.007

Grewal, D., Julie, B., Levy, M., \& Voss, G. B. (2003). The effects of wait expectations and store atmosphere evaluations on patronage intentions in service-intensive retail stores. Journal of Retailing, 79(4), 259-268. http://dx.doi.org/10.1016/j.jretai.2003.09.006

Griffiths, S. W. (2003). Learned recognition of conspecifics by fishes. Fish Fisher, 4, 256-268. http://dx.doi.org/10.1046/j.1467-2979.2003.00129.x

Gupta, S., \& Vajic, M. (2000). The contextual and dialectical nature of experiences. In Fitzsimmons, J., \& Fitzsimmons, M. (Eds.), New Service Development - Creating Memorable Experiences (pp. 33-51). Thousand Oaks, C.A : Sage.

Hair, J. F. J., Black, W. C., Babin, B. J., Anderson, R. E., \& Tatham, R. L. (2006). Multivariate data analysis. New Jersey: Pearson Education.

Hamilton, I. M., \& Dill, D. L. (2003). Group foraging by a kleptoparasitic fish: A strong inference test of social foraging models. Ecology, 84, 3349-3359. http://dx.doi.org/10.1890/02-0227

Hepbum, M. A., \& Hepburn, L. R. (1985). Case study of the acid rain film controversy: Political propaganda environmental education? Journal of Environmental Education, 141-146.

Holbrook, M. B., \& Hirschman, E. C. (1982). The experiential aspects ofconsumptionconsumer fantasy, feelings and fun. Journal of Consumer Research, 9(2), 132-140. http://dx.doi.org/10.1086/208906

Houghton Mifflin. (2006). American Heritage Dictionary of the English Language (4th ed.). Boston, M. A.: Houghton Mifflin

Howitt, D., \& Cramer, D. (2011). Introduction to SPSS statistics in psychology: For version 19 and earlier (5th ed.). Essex: Pearson Education Limited.

Hoyer, W. D., \& McInnis, D. (2001). Consumer Behavior. Boston, M.A: Houghton Mifflin.

Hulten, B., Broweus, N., \& Van Dijk, M. (2009). Sensory marketing. Hamsphire, United Kingdom: Palgrave -Macmillan. http://dx.doi.org/10.1057/9780230237049

Kim, S. H., Cha, J. M., Knutson, B. J., \& Beck, J. A. (2011). Development and testing of the customer experience index (CEI). Managing Service Quality, 21(2), 112-132. http://dx.doi.org/10.1108/09604521111113429

LeDoux, J. (1996). The Emotional Brain. New York: Simon \& Schuster.

Lewis, R. C., \& Chambers, R. E. (2000). Marketing leadership in hospitality: Foundation and practices (3rd ed.). New York: John Wiley \& Sons.

Lindstorm, M. (2005). Brand sense: Build powerful brands through touch, taste, smell, slight and sound. New York: Free Press.

Macionis, J. J., \& Plummer, K. (1997). Sociology. New York: Prentice Hall.

Malhotra, N. K. (2004). Marketing research: An applied orientation (4th ed.). New Jersey: Prentice-Hall.

Malhotra, N., \& Peterson, M. (2006). Basic marketing research: A decision-making approach (2nd ed.). New Jersey: Prentice Hall.

Meyer, C., \& Schwager, A. (2007). Understanding customer experience. Harvard Business Review, (2), 117-126.

Moretz, J. A., Martins, E. P., \& Robinson, B. D. (2007). The effects of early and adult social environment on 
zebrafish (Danio rerio) behavior. Environmental Biology Fish, 80, 91-101. http://dx.doi.org/10.1007/s10641-006-9122-4

Nagasawa, S. (2008) Customer experience management: Influencing on human Kansei to management of technology. The TQM Journal, 20(4), 312-323. http://dx.doi.org/10.1108/17542730810881302

Nohrstedt, S. A. (1991). The information crisis in Sweden after Chernoby. Media, Culture and Society, 13, 477-497. http://dx.doi.org/10.1177/016344391013004004

Oliver, R. L. (1997). Satisfaction: A behavioural perspective on the consumer. London: McGraw-Hill.

Olsen. (1993). Impact of social network on cardiovascular mortality in middle aged Danish men. Epideniiol Communit Health, 47(7), 176-180. http://dx.doi.org/10.1136/jech.47.3.176

Oxford University Press. (2006). Oxford English Dictionary. Oxford University Press.

Palmer, A. (2010). Customer experience management: A critical review of an emerging idea. Journal of Services Marketing, 24(3), 196-208. http://dx.doi.org/10.1108/08876041011040604

Pan, Y., \& Zinkhan, G. M. (2006). Determinants of retail patronage. Journal of Retailing, 82(3), $229-243$. http://dx.doi.org/10.1016/j.jretai.2005.11.008

Parkinson, B. (1996). Emotions are social. British Journal of Psychology, 87, $663-683$. http://dx.doi.org/10.1111/j.2044-8295.1996.tb02615.x

Pine, B. J., \& Gilmore, J. H. (1999). The experience economy. Boston, M. A.: Harvard Business School Press.

Pitch, T. J., \& Magurran, A. E. (1986). Dicing with dealth: Predator inspectionbehavior in minnow shoals. Journal of Fish Biology, 28, 439-448. http://dx.doi.org/10.1111/j.1095-8649.1986.tb05181.x

Powazek, D. (2001). Design for community: The art of connecting real people in virtual places. Indiana: New Riders,

Price, L. L., Arnould, E. J., \& Tierney, P. (1995). Going to extremes: Managing service encounters and assessing provider performance. Journal of Marketing, 59, 83-97. http://dx.doi.org/10.2307/1252075

Schmitt, B. H. (1999). Experiential marketing: How to get customers to sense, feel, think, act and relate to your company and brands. New York: Free Press.

Schmitt, B. H. (2003). Customer experience management: A revolutionary approach to connecting with your customer. Indianapolis: John Wiley \& Sons.

Schoenfeld, A. C., Meier, R. F., \&Griffin, R. J. (1979). Constructing a social problem: The press and the environment. Social Problems, 27, 38-61. http://dx.doi.org/10.2307/800015

Shaw, C., \& Ivens, J. (2002). Building great customer experiences. New York: MacMillan. http://dx.doi.org/10.1057/9780230554719

Sirohi, N., McLaughlin, E. W., \& Wittink, D. R. (1998). A model of consumer perceptions and store loyalty intentions for a supermarket retailer. Journal of Retailing, 74(2), 223-245. http://dx.doi.org/10.1016/S0022-4359(99)80094-3

StaEhla, T., RuEttenb, A., Nutbeamc, D., Baumand, A., Kannasa, L., Abele, T. ... Van der Z, J. (2001). The importance of the social environment for physically active lifestyle - results from an international study. Social Science and Medicine, 52, 1-10. http://dx.doi.org/10.1016/S0277-9536(00)00116-7

Vargo, S. L., \& Lusch, R. F. (2004, January). Evaluating to a new dominant logic for marketing. Journal of Marketing, 68(1), 1-17. http://dx.doi.org/10.1509/jmkg.68.1.1.24036

Verhoef, P. C., Neslie, S. A., \& Vroomen, B. (2007). Multiple-channel customer management: Understanding the research shopper phenomenon. International Journal of Research in Marketing, 24(2), 129-148. http://dx.doi.org/10.1016/j.ijresmar.2006.11.002

Walls, A. R., Okumus, F., Wang, Y. R., \& Kwun, D. J-W. (2011). An epistemological view of consumer experiences. International Journal of Hospitality Management, 30, 10-21. http://dx.doi.org/10.1016/j.ijhm.2010.03.008

Witte, D. J., \& Ryan, M. (2002). Mate choice copying in the sailfin molly, Poecilia latipinna, in the wild. Animal Behavior, 63, 943-949. http://dx.doi.org/10.1006/anbe.2001.1982

Yang, Z. Y., \& He, L. Y. (2011). Goal, customer experience and purchase intention in a retail context in China: An empirical study. African Journal of Business Management, 5(16), 6738-6746. 